\title{
Joshua ibn Gaon's Hebrew Bibles and the Circulation of Books in the Late Medieval and Early Modern Periods
}

Javier del Barco, Instituto de Lenguas y Culturas del Mediterráneo, CSIC, Madrid

\section{The manuscripts}

Joshua ben Abraham ibn Gaon of Soria, one of the finest scribes and masoretors at the turn of the fourteenth century, produced some of the most precious and magnificent Sephardic Bibles of the Middle Ages. He performed the role of scribe, masoretor, or illuminator, and in some cases all three at the same time. According to the colophons that appear in the manuscripts, he was directly involved in the production of four Bibles: Lisbon, Biblioteca Nacional de Portugal, MS Il. 72, hereinafter Cervera Bible; Oxford, Bodleian Library (Bodl.), MS Kennicott 2, hereinafter Second Kennicott Bible; Dublin, Trinity College Library (TCL), MS 16; and Paris, Bibliothèque nationale de France (BNF), MS Hébr. 20. ${ }^{1}$ Scholars have credited him with work on three other Bibles, including Parma, Biblioteca Palatina (BP), MS Parm. 2938; Bodl., MS Opp. Add. $4^{\circ} 75$ and 76; and BNF, MS Hébr. 21. ${ }^{2}$ His authorship in the Parma and Oxford

\footnotetext{
${ }^{1}$ Described as follows: the Cervera Bible, in Bezalel Narkiss, Hebrew Illuminated Manuscripts (Jerusalem: Encyclopaedia Judaica / MacMillan, 1969), Plate 6; the Second Kennicott Bible, in Catalogue of the Hebrew Manuscripts in the Bodleian Library and in the College Libraries of Oxford, ed. by Adolf Neubauer, and A. E. Cowley, 2 vols (Oxford: Clarendon, 1886-1906), no. 2323, and in Bezalel Narkiss, Aliza Cohen-Mushlin, and Anat Tcherikover, Hebrew Illuminated Manuscripts in the British Isles: A Catalogue Raisonné, 2 vols (Jerusalem: Oxford University Press for the Israel Academy of Sciences and Humanities and the British Academy, 1982), I: The Spanish and Portuguese Manuscripts, no. 3; TCL, MS 16, in Narkiss, Cohen-Mushlin, and Tcherikover, Hebrew Illuminated Manuscripts, no. 4; Paris, BNF, MS Hébr. 20, in Hermann Zotenberg and Moritz Steinschneider, Manuscrits orientaux: Catalogues des manuscrits hébreux et samaritains de la Bibliothèque impériale (Paris: Imprimerie Impériale, 1866), p. 3, and in Javier del Barco, Bibliothèque nationale de France: Hébreu 1 à 32; Manuscrits de la bible hébrä̈que, Manuscrits en caractères hébreux conservés dans les bibliothèques publiques de France (Turnhout: Brepols, 2011), pp. 112-20.

${ }^{2}$ Described as follows: BP, MS Parm. 2938, in Giovanni Bernardo De Rossi, Mss. Codices hebraici biblioth. I. B. De Rossi accurate ab eodem descripti et illustrati, (Parma: Ex Publico Typographeo, 1803), no. 341, and in Binyamin Richler and Malachi Beit-Arie, Hebrew Manuscripts in the Biblioteca Palatina in Parma: Catalogue (Jerusalem: Jewish National and University Library, 2001), no. 14; Bodl. MS Opp. Add. $4^{\circ} 75$ and 76, in Neubauer and Cowley, Catalogue of the Hebrew Manuscripts in the
} 
Bibles is debated. ${ }^{3}$ In the case of BNF, MS Hébr. 21, Ibn Gaon had an important role in its production, although it is not entirely clear that he was the only scribe and artist working on this manuscript.

This group of Bibles is of particular interest for many reasons. It comprises one of the most comprehensive manuscript productions - all of them lavishly decorated Hebrew Bibles - attributed to a single, identified Jewish scribe in the Middle Ages. In addition, the manuscripts contain different historical annotations and deeds, opening the door to trace their transmission and circulation, and thus to pave the way to understand the early history of these books. The production and decoration of these Bibles have been the object of particular attention from numerous art historians, including Cecil Roth, Bezalel Narkiss, Gabrielle Sed-Rajna, Thérèse Metzger and Katrin KogmanAppel. ${ }^{4}$ Such attention has raised several issues concerning the production of these Bibles, such as the ascription of some codices to Ibn Gaon, the chronology of the manuscripts, the place of production, and the persons involved as patrons and as actual producers of the manuscript. It has also increased our knowledge of Bible production and patronage, as well as of biblical illumination. Nevertheless, the history of the use

Bodleian, nos 68-69; and in Narkiss, Cohen-Mushlin, and Tcherikover, Hebrew Illuminated Manuscripts, no. 5 (corresponding to Neubauer no. 68; no. 69 is not mentioned at all); BNF, MS Hébr. 21, in Zotenberg and Steinschneider, Manuscrits orientaux, p. 3, and in del Barco, Bibliothèque nationale de France, pp. 124-30.

${ }^{3}$ Cf. Katrin Kogman-Appel, Jewish Book Art Between Islam and Christianity: The Decoration of Hebrew Bibles in Medieval Spain, The Medieval and Early Modern Iberian World (Leiden: Brill, 2004), pp. 10304; Narkiss, Cohen-Mushlin, and Tcherikover, Hebrew Illuminated Manuscripts, no. 5; Thérèse Metzger, 'Josué ben Abraham ibn Gaon et la masora du Ms. Iluminado 72 de la Biblioteca Nacional de Lisbonne', Codices manuscripti, 15, no. 5 (1990), p. 2n10.

${ }^{4}$ Cf. Cecil Roth, 'A Masterpiece of Medieval Spanish-Jewish Art: The Kennicott Bible', in his book Gleanings; Essays in Jewish History, Letters, and Art (New York: Published by Hermon Press for Bloch, 1967), pp. 298-321; Narkiss, Cohen-Mushlin, and Tcherikover, Hebrew Illuminated Manuscripts, nos 36; Bezalel Narkiss and Gabrielle Sed-Rajna, 'Manuscrits hébreux enluminés conservés dans les bibliothèques de France: Présentation et spécimen', Revue des études juives, 130, nos 2-4 (1971), 25569; Gabrielle Sed-Rajna and Sonia Fellous, Les manuscrits hébreux enluminés des bibliothèques de France, ed. by Maurits Smeyers, Corpus van verluchte handschriften = Corpus of Illuminated Manuscripts (Leuven: Peeters, 1994), nos 15-16; Metzger, 'Josué ben Abraham ibn Gaon'; KogmanAppel, Jewish Book Art, chap. 4. Ibn Gaon's Bibles have also been the object of: Estelle Halevy-Goitein, 'The Illuminated Manuscripts of Joshua ben Abraham ibn Gaon' (unpublished doctoral thesis, École Pratique des Hautes Études, 1982). 
and circulation of these manuscripts subsequent to their completion has mostly been neglected and remains to be examined. How were these Bibles used and read? By whom? How were they transmitted? What itineraries did they follow? These and other questions still await an answer, which in most cases is hidden in the manuscripts themselves, in the form of colophons, ${ }^{5}$ deeds of sale, deeds of inheritance and other annotations. The lack of interest, with a few exceptions, ${ }^{6}$ in the use and circulation of Hebrew manuscripts in general after their production and in the ways they were transmitted and collected is to be attributed, on the one hand, to the focus on manuscript decoration and production given by art historians and codicologists, and, on the other hand, to the scarce attention given to the many deeds and annotations written on several manuscripts by owners, readers, buyers and their heirs. ${ }^{7}$

\footnotetext{
${ }^{5}$ Colophons are already being used as historical sources, giving precious information to help understand manuscript production in its historical and cultural context; see for example Michael Riegler, 'Colophons of Medieval Hebrew Manuscripts as Historical Sources' [in Hebrew] (unpublished doctoral thesis, The Hebrew University of Jerusalem, 1995).

${ }^{6}$ For example, Colette Sirat, 'Notes sur la circulation des livres entre Juifs et Chrétiens au Moyen Age', in Du copiste au collectionneur: Mélanges d'histoire des textes et des bibliothèques en l'honneur d'André Vernet, ed. by Donatella Nebbiai-Dalla Guarda, and Jean-François Genest (Turnhout: Brepols, 1999),
} 383-403. More research has been done on the study of medieval and early modern libraries following the publication of different lists of Hebrew books; cf. Eleazar Gutwirth and Miguel Ángel Motis Dolader, 'Twenty-Six Jewish Libraries from Fifteenth-Century Spain', The Library: The Transactions of the Bibliographical Society, 18, no. 1 (1996), 27-53; Shifra Baruchson-Arbib, La culture livresque des juifs d'Italie à la fin de la Renaissance, Documents, études et répertoires (Paris: CNRS, 2001); The Hebrew Book in Early Modern Italy, ed. by Joseph Hacker and Adam Shear (Philadelphia: University of Pennsylvania Press, 2011); Menahem Schmelzer, 'Hebrew Manuscripts and Printed Books among the Sephardim Before and After the Expulsion', in Crisis and Creativity in the Sephardic World, 1391-1648, ed. by Benjamin R. Gampel (New York: Columbia University Press, 1997), pp. 257-66; Menahem Schmelzer, 'A Fifteenth-Century Hebrew Book List', Studies in Bibliography and Booklore, 20 (1998), 89-98.

${ }^{7}$ Only recent catalogues transcribe these annotations, either in their entirety or in part. See, for example, Richler and Beit-Arie, Hebrew Manuscripts in the Biblioteca Palatina; Binyamin Richler, Malachi BeitArie, and Nurit Pasternak, Hebrew Manuscripts in the Vatican Library: Catalogue (Vatican City: Biblioteca Apostolica Vaticana, 2008); Philippe Bobichon and Georges Vajda, Bibliothèque nationale de France, Hébreu 669 à 703: Manuscrits de théologie, Manuscrits en caractères hébreux conservés dans les bibliothèques de France: Catalogues (Turnhout: Brepols, 2008); Silvia Di Donato, Bibliothèque nationale de France, Hébreu 214 à 259: Commentaires bibliques, Manuscrits en caractères hébreux conservés dans 
The history of Sephardic Hebrew manuscripts in general - and that of Ibn Gaon's Bibles in particular — is one of migration and mobility connected with the 1391 riots and subsequent expulsions in the Iberian Peninsula from 1483 to 1498 . Most of the medieval Sephardic codices are extant in different libraries outside the Iberian Peninsula, and the few that are kept on Iberian soil come, except for particular cases, from purchases and bequests related to royal and ecclesiastical patronage. ${ }^{8}$ As far as Joshua ibn Gaon's Bibles are concerned, all of them are extant in libraries in France or in the British Isles, except for the Cervera Bible, which is housed in the Biblioteca Nacional de Portugal in Lisbon. ${ }^{9}$ It is thus highly opportune to scrutinize the history of

les bibliothèques de France: Catalogues (Turnhout: Brepols, 2011) ; del Barco, Bibliothèque nationale de France.

8 The two most important collections of medieval Hebrew manuscripts in Spain, those of the Biblioteca Nacional de España and the Real Biblioteca de San Lorenzo de El Escorial, were built upon royal patronage with acquisitions and bequests from noblemen and ecclesiastical institutions: the collection of the Biblioteca Nacional de España in Madrid was mainly built upon Cardinal Zelada's collection, coming from Rome to the Cathedral of Toledo and later to Madrid, and upon some manuscripts from the Convent of St Martin in Madrid; the collection of the Real Biblioteca de El Escorial was built in the sixteenth century upon Benito Arias Montano's acquisitions in Italy and Flanders, noblemen's bequests and some manuscripts from the Inquisition; see María Teresa Ortega-Monasterio, 'La Biblioteca de El Escorial: Sus fondos hebreos', in El manuscrito hebreo bíblico de la biblioteca de San Lorenzo de El Escorial, ed. by María Josefa Azcárraga Servet, Emilia Fernández Tejero, and María-Teresa Ortega-Monasterio (Madrid: Testimonio, 2000), pp. 33-54; María Teresa Ortega-Monasterio, 'Las bibliotecas y sus manuscritos hebreos', in Catálogo de manuscritos hebreos de la Comunidad de Madrid, ed. by Javier del Barco, Serie A: Literatura Hispano-hebrea, 3 vols (Madrid: CSIC, 2003-06), I (2003), 17-62 (pp. 34-55); and 'Las bibliotecas y sus manuscritos hebreos', Catálogo de manuscritos hebreos, ed. by del Barco, II (2004), 1943.

${ }^{9}$ The presence of the Cervera Bible in Lisbon results from reasons other than those that brought the rest of the manuscripts into British or French collections. In the latter cases, the interest in collecting 'oriental' manuscripts, which started in the seventeenth and eighteenth centuries, was the main reason that led to the growth of collections already patronized by royalty, ecclesiastical institutions or universities. The Bibliothèque nationale de France, for instance, added to the Royal collection Cardinal Mazarin's Hebrew manuscripts, Colbert's collection, Hebrew manuscripts from the Oratoire de Paris and some others from La Sorbonne and the Abbey of Saint-Germain-des-Prés. The Hebrew manuscripts from the Oratoire de Paris were collected in Istanbul by Achille de Harlay de Sancy while ambassador to the Ottoman Empire; cf. Sed-Rajna and Fellous, Les manuscrits hébreux enluminés, VII-X, and Francis Richard, 'Achille de Harlay de Sancy et ses collections de manuscrits hébreux', Revue des études juives, 149, no. 4 (1990), 
these manuscripts in order to understand book circulation and transmission, and to know the places where they have been, the itineraries they have followed, and the people who have read them. In what follows, I shall raise some issues concerning the production of Ibn Gaon's Bibles, but particularly other issues concerning their ownership, transmission, circulation, and use over the first centuries of their existence. I shall therefore pay attention to the manuscript as a historical object, and as a problem posing multiple questions regarding patrons, scribes, owners, readers and users; a problem to which a method based on codicology, palaeography and the examination of historical annotations may provide some answers. My analysis will focus on two particular manuscripts in which all these questions are extremely pertinent - BNF, MS Hébr. 20 and 21 , two codices which, by the way, have not been randomly selected among the Bibles of Ibn Gaon. Both manuscripts are luxury Hebrew Bibles which were successively produced by Ibn Gaon in Tudela (Navarre, in present-day Spain) at about the turn of the fourteenth century. In both cases, questions regarding production and patrons are very similar; both manuscripts were already in circulation in the fourteenth century, and were sold, read and used in such distant places from Tudela as Lisbon and Bologna. Moreover, the many deeds and annotations in these two Bibles help us to trace the itineraries they followed and the owners who used them until they entered the Bibliothèque nationale de France in the eighteenth century. The questions regarding their circulation and use during the late-medieval and early-modern periods are analogous, and make the joint study of both Bibles significant, fruitful and enlightening.

\section{Patrons and scribes}

In this part of the article I focus on the people involved in the production of the two Bibles under analysis whom I have described roughly as patrons and scribes. The foremost scribe and artist concerning me will of course be Joshua ibn Gaon. Indeed, he was commissioned to produce both manuscripts at about the turn of the fourteenth century.

Very few of his biographical details are known to us. He was born in Soria, probably in the last third of the thirteenth century, the son of Abraham ibn Gaon of Soria, and carried on his activities mainly in Tudela, about 90 kilometres from Soria,

417-47. In contrast, the Cervera Bible was acquired in The Hague for the Portuguese Royal Library at the beginning of the nineteenth century, as a result of the particular interest of the Royal Librarian. 
and one of the biggest and most important Jewish communities in Navarre, with the advantage, like Soria in Castile, of being a frontier town on an important trade route linking Castile, Navarre and Aragon, at that time separate kingdoms. His father must have been a learned and respected person, as we can infer from the words of Solomon ben Hasdai, himself a reader of one of Joshua's Bibles at the end of the fourteenth century, about whom I shall give further details below. Referring to Abraham ibn Gaon of Soria in a deed of sale, Solomon wrote: 'הגאון ראש גולת אריאל עטרת תפארת ישראל ר' אברהם תנצב"ה ('The Gaon, head of Ariel's exile, glorious crown of Israel, R. Abraham, may his soul rest in wellbeing'). ${ }^{10}$

Joshua's brother was the famous Kabbalist Shem Tov ben Abraham ibn Gaon, the author of Migdal 'oz, a commentary on Maimonides' Mishneh torah. Shem Tov, himself also a scribe, copied a Bible dated 1312 in Soria, the so-called Keter Shem Tov. ${ }^{11}$ No other biographical indication is known to us except what is said in the colophon that Joshua wrote on the reverse side of a bifolium containing a plan of the Temple. This bifolium is placed at the beginning of the Second Kennicott Bible, one of the manuscripts copied by Ibn Gaon. There, Joshua states: וזה כתבתי וציירתי אני הקטן ('I, tiny young Joshua, son of Abraham ibn Gaon of Soria, wrote and painted this [the plan of the Temple], as I have learned (or 'when I was learning”: כאשר למדת) from the sage Rabbi Isaac bar Gershom'). ${ }^{12}$

The reference to his apprenticeship as scribe and illuminator under Isaac bar Gershom is difficult to match with the date indicated in the colophon, $1306,{ }^{13}$ for by

\footnotetext{
${ }^{10}$ BNF, MS Hébr. 20, fol. 466 .

${ }^{11}$ Bermuda, Carl Alexander Trust for Art and Judaica, formerly London, Sassoon Library, MS 82. Described in David Solomon Sassoon, Ohel Dawid: Descriptive Catalogue of the Hebrew and Samaritan Manuscripts in the Sassoon Library, London, 2 vols (London: Oxford University Press, H. Milford,
} 1932), I, 2-5, and A Further Ninety-Seven Highly Important Hebrew Manuscripts from the Collection Formed by the Late David Solomon Sassoon [...]: Auction, Tuesday December 4, 1984 (New York: Sotheby's, 1984), no. 97.

${ }^{12}$ Second Kennicott Bible, fol. $1^{\mathrm{v}}$.

${ }^{13}$ According to Narkiss, Cohen-Mushlin, and Tcherikover, Hebrew Illuminated Manuscripts, no. 3, the Second Kennicott Bible was produced in 1306, as was the plan of the Temple attached to it. However, Kogman-Appel, Jewish Book Art, pp. 101-02, has demonstrated, basing her assumptions on the analysis of the artistic motifs, that both the Bible and the plan of the Temple are early works, independently copied and illuminated by Ibn Gaon before BNF, MSS Hébr. 20 and 21. The date and place — Soria, 1306 - 
this date Ibn Gaon had already worked on most of the Bibles on which he collaborated, including the Second Kennicott Bible itself, the Cervera Bible, and BNF, MSS Hébr. 20 and 21. As Kogman-Appel has noted, the date and place - as well as the name of the Bible's patron, Moses ibn Haviv — are written in ink different from the rest of the colophon, and could have been added some years after the production of both the Bible and the plan of the Temple. ${ }^{14}$ His words paying tribute to his teacher should thus not be dated to 1306 , but most probably to the beginning of his career.

Joshua must have been active in the city of Tudela from before 1300 - when he produced BNF, MS Hébr. 20 and started BNF, MS Hébr. 21 - and returned to Soria at some point between 1302 and 1306. Back in Soria, in 1306 he sold the Second Kennicott Bible, together with the plan of the Temple. ${ }^{15}$ It was in Tudela that, according to Kogman-Appel, he may have met Joseph ha-Ṣarfati, with whom he worked on the Cervera Bible. ${ }^{16}$ During his stay in Tudela, Joshua worked at a frenetic pace. Both manuscripts under examination here, BNF, MSS Hébr. 20 and 21, were produced there, as stated in their colophons, ${ }^{17}$ and in both he assumed the three-fold activity of scribe, masoretor and illuminator. ${ }^{18}$

indicated in fol. $2^{\mathrm{v}}$ of the Second Kennicott Bible would only refer to the moment and place in which the manuscript, including the plan of the Temple, was sold.

${ }^{14}$ Kogman-Appel, Jewish Book Art, p. 101.

${ }^{15}$ Kogman-Appel, Jewish Book Art, p. 113.

${ }^{16}$ Kogman-Appel, Jewish Book Art, p. 126.

${ }^{17}$ In BNF, MS Hébr. 20, the name of the city is mentioned three times, twice in fol. $45^{\mathrm{r}}$, in respective colophons hidden in the micrographic Masorah magna, one on the lower margin and one on the outer margin, and once in fol. $69^{\mathrm{r}}$, also hidden in the micrographic Masorah magna in the lower margin; cf. Metzger, 'Josué ben Abraham ibn Gaon', p. 2n13, and del Barco, Bibliothèque nationale de France, pp. 114-15. In BNF, MS Hébr. 21, the name of the city is mentioned in fol. $263^{\mathrm{v}}$, again hidden in a colophon which is part of a micrographic motif also containing the list of hillufin Ben Asher and Ben Naftali. There Ibn Gaon confirmed that he was the masoretor of the Bible; cf. del Barco, Bibliothèque nationale de France, p. 127. This colophon was first mentioned by Metzger, 'Josué ben Abraham ibn Gaon', p. 2n16. ${ }^{18} \mathrm{Ibn}$ Gaon identified himself as the masoretor in both manuscripts, and as the scribe in BNF, MS héb. 20. The script in BNF, MS Hébr. 21 is in his hand, as is the script in the first quire of this manuscript, for which he claimed being the 'producer'. Cf. del Barco, Bibliothèque nationale de France, pp. 126-27. Concerning the illumination, Kogman-Appel, Jewish Book Art, 115 comes to the conclusion that the illumination in BNF, MS Hébr. 21 is also Ibn Gaon's, and that 'its painting is more mature that that of the others'. A different opinion is held by Sed-Rajna and Fellous, Les manuscrits hébreux enluminés, no. 16. 
It seems that BNF, MSS Hébr. 20 and 21 were not the only manuscripts produced by Ibn Gaon in Tudela, as two other Bibles may have been copied there as well. Kogman-Appel claims that Joshua and Joseph ha-Șarfati met in Tudela and that subsequently Ibn Gaon worked on the Second Kennicott Bible just before producing BNF, MS Hébr. 20. After the production of the Parisian Bibles, he and Joseph haȘarfati must have collaborated, also in Tudela, on the production of the Cervera Bible. ${ }^{19}$ If we accept her suggestions, we may assume that Ibn Gaon's frenetic activity would not have been possible if carried out by him alone. ${ }^{20}$

In fact, many aspects of his work can only be understood if we assume that most of the Bibles were produced in an actual workshop of manuscript production. In the case of BNF, MS Hébr. 21, Sed-Rajna, assuming that 'l'ensemble du décor était probablement le travail de son atelier' ('the entire decoration was probably the work of his workshop'), described the decorations in this manuscript as 'médiocres copies de modèles communs' ('mediocre copies of common patterns'). ${ }^{21}$ As far as the Cervera Bible is concerned, Metzger claims that the Masorah magna was not copied by Ibn Gaon alone, and concludes that while Ibn Gaon copied the Masorah of an equivalent of twenty-one quires, another unknown masoretor completed the Masorah of an equivalent of fifteen quires. ${ }^{22}$ In the case of BP, MS Parm. 2938, where Ibn Gaon's authorship is disputed, Narkiss accepts that its production may be attributed to Joshua ibn Gaon's hand; but Kogman-Appel doubts this, and suggests that 'the work may have been done

\footnotetext{
${ }^{19}$ Kogman-Appel, Jewish Book Art, pp. 126-27.

${ }^{20}$ According to Kogman-Appel's chronology of the manuscripts, Ibn Gaon was involved in the work of six Bibles in a very short time-span, from 1298 or 1299 to 1301/02. He was the scribe and the masoretor in all of them, except for the Cervera Bible, where he was not the scribe, and he was involved in the illumination of four of them - the Second Kennicott Bible, BNF, MSS Hébr. 20 and 21, and TCL, MS 16. If this is correct, it is very unlikely that Ibn Gaon worked alone. Colette Sirat, Hebrew Manuscripts of the Middle Ages (Cambridge: Cambridge University Press, 2002), p. 223, states that the average production of a scribe was one folio per day, and adds 'this low rate of productivity is partly explained by the fact that copying was mostly an activity making up the salary of a schoolteacher, cantor or judge [...] It is therefore not a full-time occupation, at any rate before the Renaissance'.

${ }^{21}$ Sed-Rajna and Fellous, Les manuscrits hébreux enluminés, no. 16. Kogman-Appel, Jewish Book Art, p. 112 suggests that the difference of technique in the illumination of BNF, MSS Hébr. 20 and 21 might reflect technical development, although she also accepts the possibility of the participation of 'another, untrained colorist'.

${ }^{22}$ Metzger, 'Josué ben Abraham ibn Gaon', p. 7.
} 
under Joshua's influence or even supervision, but his role in its actual execution would have been very small'. ${ }^{23}$ If even the Masorah magna, in which Ibn Gaon developed his best skills, could have been a collaborative work, as in the Cervera Bible (despite Joshua's claims in his colophons), the same can be certain of his work as scribe, and we cannot escape the possibility that BNF, MS Hébr. 20 was also produced in collaboration with other scribes or masoretors. In conclusion, the evidence indicates that he did not work alone, and the existence of a manuscript workshop based in Tudela, in which Joshua collaborated or which he even may have run, should probably be accepted. ${ }^{24}$ If I am right in assuming the existence of such a workshop, it is then reasonable to think that the manuscripts produced there were commissioned by wealthy people from Tudela and the surrounding area, including La Rioja and Soria in Northern Castile, and the neighbouring areas in Aragon. ${ }^{25}$ This assumption does not seem to match with the information given in the colophon of the Cervera Bible, where the patron, Rabbi Sassoon, is mentioned as being from Cervera. The most famous town of this name, with a documented Jewish community in the fourteenth century, is Cervera in Catalonia. Nevertheless, Kogman-Appel claims that Rabbi Sassoon may have been a wealthy Jew from another place, namely Cervera del Río Alhama, a small town forty kilometres from Tudela on the other side of the Castilian border, in La Rioja. ${ }^{26}$ Her assumption that

\footnotetext{
${ }^{23}$ Narkiss, Cohen-Mushlin, and Tcherikover, Hebrew Illuminated Manuscripts, p. 23; Kogman-Appel, Jewish Book Art, p. 104.

${ }^{24}$ Halevy-Goitein, 'The Illuminated Manuscripts', p. 97, accepts not only that Ibn Gaon worked in a workshop, but also suggests that 'in the thirteenth century Jewish workshops came into being parallel to the development of lay workshops in Latin Europe'. Nonetheless, this generalization should be taken with caution, and every particular case should be examined according to the existing evidence.

${ }^{25}$ Places with documented Jewish communities in an area of about fifty kilometres from Tudela include Calahorra in La Rioja, Ágreda in Soria and Tarazona in Aragon. Soria and Zaragoza are more distant, but less than ninety kilometres from Tudela.

${ }^{26}$ Other possibilities are Cervera de los Montes in Toledo or any of the other 'Cerveras' in the Iberian Peninsula, of which three are in the kingdom of Castile (Cervera de Buitrago, Cervera del Llano and Cervera de Pisuerga), and two in the Crown of Aragon (Cervera del Rincón and Cervera del Maestre). All of them are much farther away from Tudela than Cervera del Río Alhama. The option of Cervera in Catalonia is claimed as the right one by Metzger, 'Josué ben Abraham ibn Gaon', 8n51, who thinks that the possibility of Cervera del Río Alhama is 'une hypothèse à écarter' ('an hypothesis to reject'), with no other explanation. Narkiss, Cohen-Mushlin, and Tcherikover, Hebrew Illuminated Manuscripts, pp. 1617, consider the Cervera Bible as a manuscript typical of the Castilian school produced in Cervera in Castile with no further indication - probably Cervera de los Montes in Toledo.
} 
this Bible could not be from Cervera in Catalonia is based on the presence of seder markings, ${ }^{27}$ absent from Catalonian Bibles and therefore not necessary for a Catalan patron who would probably not have requested them. Likewise, many other scribes and workshops were available closer to Cervera in Catalonia than distant Tudela in Navarre, where Joseph ha-Șarfati and Joshua ibn Gaon eventually worked together on the Cervera Bible. ${ }^{28}$ Moreover, the presence in this Bible of a three-turreted castle - the emblem of Castile since Alfonso VIII (1158-1214) — in the upper margin of fol 207 ${ }^{\mathrm{r}}$, does not seem to fit in a book for a Catalan patron. ${ }^{29}$ This assumption leads us to deduce that the other Bibles produced by Joshua in Tudela — including BNF, MSS Hébr. 20 and 21 - were also commissioned by patrons from this city and the surrounding area.

In the case of BNF, MS Hébr. 21, an initial and somewhat special quire, ${ }^{30}$ entirely illuminated by Ibn Gaon, mentions the name of the patron. This mention surrounds the decoration of the carpet page preceding the rotating calendars in the same quire, and states: אני יהושע ב"ר אברהם ן' גאון נר"ו עשיתי זה הקונדרים ראשון לזה הספר ליקר (I, Joshua son of Abraham ibn הנכבד הרופא ר' אברהם די ליריאה בן ה[...] ויגדל לעד כבודו אמן Gaon - may the Merciful protect him and bless him — have made this first quire of this book for the esteemed and worthy physician R. Abraham de Leria, son [...] - may his honour increase for eternity - Amen'). ${ }^{31}$ The reading of דיריאה is not univocal. Possible readings include Liria, a small village near the city of Valencia, or Leiria, the well-known Portuguese town, north of Lisbon, but even more distant from Tudela than

\footnotetext{
${ }^{27}$ The seder markings reflect the old Palestinian triennial cycle of reading of the Bible, which was superseded by the Babylonian annual cycle. In Iberian Hebrew manuscripts, seder markings appear only in some Castilian Bibles.

${ }^{28}$ Kogman-Appel, Jewish Book Art , pp. 125-26.

${ }^{29}$ Nevertheless this last evidence may not be related with the patron but with Ibn Gaon himself, as he used the motif of the three-turreted castle and that of the rampant lion - the emblem of the kingdom of León - in other manuscripts, such as the Second Kennicott Bible and BNF, MS Hébr. 21; cf. Narkiss, Cohen-Mushlin, and Tcherikover, Hebrew Illuminated Manuscripts, p. 29; del Barco, Bibliothèque nationale de France, p. 126.

${ }^{30}$ There are differences in the style of the illuminations between those in this quire and those in the rest of the manuscript. However, these could be attributed either to the development of Joshua's style or to the participation of another artist. Moreover, similarities in other aspects, such as the type of script and the artistic repertoire used throughout the Bible, lead us to suggest that Ibn Gaon, perhaps with collaboration, produced the entire manuscript.
}

${ }^{31}$ BNF, MS Hébr. 21, fol. $1^{v}$. 
Liria in Valencia. ${ }^{32}$ Nevertheless, accepting my opinion that Ibn Gaon ran a workshop in Tudela, where he worked on the production of at least six Bibles in less than a fiveyear time span, and that the manuscripts would have been commissioned at Ibn Gaon's workshop from patrons living in the more restricted area of Tudela and its surroundings, it seems more plausible to identify the toponym as Leria, ${ }^{33}$ a small village north of Soria in the vicinity of Yanguas, near San Pedro Manrique and ninety kilometres from Tudela. ${ }^{34}$ This said, it cannot be excluded that even if the physician Abraham were from Leria, it is most likely that he ran his practice as a physician in Tudela, where the Bible was produced by Ibn Gaon and his workshop.

In contrast with this Bible, BNF, MS Hébr. 20 and the Second Kennicott Bible have no indication whatsoever about the patron. ${ }^{35}$ Nevertheless, accepting what has been argued in the cases of both the Cervera Bible and BNF, MS Hébr. 21, namely that both manuscripts were produced in the area near Tudela for patrons living in the area, we can infer that both BNF, MS Hébr. 20 and the Second Kennicott Bible may also have been produced in Joshua's workshop for patrons living in Tudela, or in an area that can be traced by a triangle linking the towns of Tudela, Soria and Calahorra. ${ }^{36}$ In the case of BNF, MS Hébr. 20, the absence of any mention of the patron needs further comment. This Bible is a sumptuous artefact that must have been produced for a person

\footnotetext{
${ }^{32}$ Michel Garel, D’une main forte: Manuscrits hébreux des collections françaises (Paris: Seuil / Bibliothèque nationale, 1991), no. 46: 'commandité par le médecin Abraham de Liria, près de Valence (et non de Leiria, au Portugal)'.

33 This possibility has already been suggested by Sed-Rajna and Fellous, Les manuscrits hébreux enluminés, p. 46. Halevy-Goitein, 'The Illuminated Manuscripts', also transcribed the toponym as Leria, but adding a question mark and with no reference to the identification of the place.

${ }^{34}$ Both Yanguas and San Pedro Manrique are mentioned in medieval documents as places with a Jewish population; cf. Francisco Cantera Burgos, 'Juderías medievales de la provincia de Soria', in Homenaje a Fray Justo Pérez de Urbel, O.S.B., 2 vols (Silos: Abadía, 1976), I, 445-82 (p. 471).

35 The name of the first owner of the Second Kennicott Bible, Moses ibn Haviv, was copied in the colophon in 1306, several years after the Bible and the plan of the Temple attached to it were produced. Cf. Kogman-Appel, Jewish Book Art, pp. 101-02.

${ }^{36}$ A different opinion is sustained by Metzger, 'Josué ben Abraham ibn Gaon', 8n51 and 52. Supporting the idea that the Cervera Bible was copied in Cervera in Catalonia by Samuel ibn Natan and then sent to Tudela to Ibn Gaon, she reaches the conclusion that a single Hebrew book may often have been produced in different places corresponding to stages of production, thus reflecting the exchanges and relations among Jewish communities throughout Iberia.
} 
of prominence in Ibn Gaon's community, probably from Tudela or the surrounding area. Strikingly, while Joshua wrote his own name in several places hidden in the Masorah magna, the name of the patron is unknown to us, as is the name of any owner of the manuscript in the first century of its existence. The name of the patron would usually appear in a colophon at the end of the manuscript, but such a colophon does not exist. Instead, we find a statement documenting the sale of the manuscript one century later, in 1398/99. This statement was copied at the end of the biblical text, in Sephardic square script, as if it were the colophon. ${ }^{37}$ The original colophon, probably with the name of the patron, was erased by the person who bought the manuscript one century later, and the mentioned deed of sale was copied instead. No other annotation was copied before the sale of the Bible in 1398/99. Only in that year did Solomon ben Hasdai, whom we mentioned above, attest the acquisition of the manuscript. This same Solomon also mentioned the fact that Joshua ibn Gaon had copied the Bible, and indicated one of the places where the scribe wrote a colophon, hidden in the decoration of the micrographic Masorah magna. ${ }^{38}$

To sum up, previous assumptions regarding the place of production of the Cervera Bible and the date of the Second Kennicott Bible need be reconsidered following Kogman-Appel's claims in this regard. Assuming that both Bibles were commissioned by local patrons before 1300, BNF, MSS Hébr. 20 and 21 are to be considered as a continuation of Ibn Gaon's production service to local patrons, working mainly for the needs of the community in Tudela and in an area between this city and the neighbouring areas in Castile and Aragon, including Soria, Calahorra and Tarazona. The production of this number of luxury Bibles in such a short time-period seems unlikely for one single scribe and illuminator. Furthermore, the mention of other scribes and artists in some of Ibn Gaon's Bibles, together with evidence reflecting collaboration in almost his entire production, points to the existence of an actual workshop of manuscript production, serving local needs and patrons.

\footnotetext{
${ }^{37}$ BNF, MS Hébr. 20, fol. $466^{\mathrm{v}}$.

${ }^{38}$ This first indication by Solomon ben Hasdai gave the clue to successive scholars in finding Ibn Gaon's colophons hidden in the Masorah magna. Cf. Metzger, 'Josué ben Abraham ibn Gaon', p. 2n13.
} 


\section{Owners and readers}

BNF, MS Hébr. 20 represents a paradigm in which owners and readers adopted an active role in the transformation of the manuscript over time, and the traces they left in the pages of the book become the primary evidence for analyzing the uses of the manuscript. This analysis is critical to understand the ways in which books were read, collected and transmitted. In this Bible, Solomon ben Hasdai, the first attested buyer of the Bible, was not only a reader but also an active user and scribe, as will be shown further below. But what do we know about Solomon ben Hasdai? First of all, we know that he lived in the area of Bologna and Ferrara at the end of the fourteenth century, as attested in the different deeds of sale in the manuscript. Second, he was a scribe himself, as evidenced by the many texts copied by his hand in the blank pages of the manuscript. Third, he was the buyer of a lavishly decorated Bible, which means that he was fairly wealthy and familiar with the book trade. Indeed, the fact that he sold the Bible on 15 of Tammuz 1399 (19 June 1399), only a few months after he bought it, may indicate that he was actually in the business of book copying and trading.

Further evidence of this is attested in another manuscript in Parma, ${ }^{39}$ a twovolume Bible which contains a deed of sale recording that Solomon ben Hasdai purchased that Bible on 3 Tishri 5160 (3 September 1399). In this manuscript, Solomon added parts of the Targum to Genesis and of Rashi's commentary to Genesis. Moreover, his role as scribe is corroborated by three other Bibles copied by him..$^{40}$ In one of them (Florence, Biblioteca Mediceo Laurentiana [BML], MS II.1), the colophon states that Ben Hasdai copied it in Ferrara in 1396. The colophons of the other two Bibles do not give a date or a place, but the information given in BNF, MS Hébr. 20, BP, MS Parm. 3290 and BML, MS II.1 allows us to situate Solomon's activity between 1395 and 1400 in the area of Ferrara and Bologna.

Yet Solomon ben Hasdai was not the first owner of the Paris 20 Bible in Italy. The earliest deed of sale in this manuscript, dated to 1398/99, records Solomon's acquisition of the Bible from Menahem ben Moses, מהספרים שחלקו הוא וכמ"ר שלמה י"ץ

\footnotetext{
${ }^{39}$ BP, MS Parm. 3290. Described in De Rossi, Mss. Codices hebraici biblioth., no. 716, and Richler and Beit-Arie, Hebrew Manuscripts in the Biblioteca Palatina, no. 180.

${ }^{40}$ Moscow, National Library of Russia, MS Guenzburg 119, copied for his own use, as stated in the colophon; BML, MSS III.1 and II.1. Cf. Catalogue of the Institute of Microfilmed Hebrew Manuscripts $<$ http://aleph.nli.org.il/F/?func=file\&file name=find-b\&local base=nnlmss $>$ [accessed 19 June 2012].
} 
בכ"'among the books that he has shared with R. Solomon ben R. Jedidiah and with R. Eliezer, and I bought it with the intercession of R. Judah Finzi'). ${ }^{41}$ We have to assume that Menahem ben Moses was the previous owner, and that he had received the Bible after 'sharing' a lot of books with two other people. Such a statement might be understood as an inheritance, but the transaction remains unclear as the three people who shared the books do not seem to be brothers. ${ }^{42}$ Whatever the case may be, Menahem ben Moses is mentioned here as the seller in a transaction taking place in Bologna in 1399 with the intercession of Judah Finzi. Another manuscript in Parma, ${ }^{43}$ containing the Astronomical Tables of Jacob ben David Bonjorn, was copied by a scribe named Menahem ben Moses for his own use in Bologna in 1394/95. It is not difficult to suggest that both men called Menahem ben Moses are the same person, as they are attested in both cases in the same city and with a difference of only four years. Moreover, as in the deed of sale in BNF, MS Hébr. 20, some members of the Finzi family appear in this case as successive owners after Menahem ben Moses himself: Solomon Finzi and Moses ben Menahem ben Moses ben Menahem ben Moses Finzi! Such a mention may indicate that the first Menahem ben Moses, the scribe and first owner of the aforementioned Parma manuscript, might not only be the same person as the Menahem ben Moses who sold BNF, MS Hébr. 20, but also a member of the Finzi family. Unfortunately, this tells us nothing about the previous owners of the manuscript, and many questions remain unanswered. What happened to the Bible after it was given to its first owner in Tudela? Why are there no traces of previous owners in the fourteenth century? Who took the manuscript to Bologna?

As in this case, the fate of BNF, MS Hébr. 21 in the first decades after its production remains obscure. It has been argued above that the first owner, the physician Abraham de Leria, probably ran his practice in Tudela, where he commissioned the Bible from Ibn Gaon, or perhaps visited Ibn Gaon's workshop and selected a Bible already in the process of being copied, and ordered a first, decorated quire to be added

\footnotetext{
${ }^{41}$ BNF, MS Hébr. 20, fol. 466 .

${ }^{42}$ At least two of them were definitely not brothers, as indicated by their patronymic: Menahem ben Moses and Solomon ben Jedidiah.

${ }^{43}$ BP, MS Parm. 2275. Described in De Rossi, Mss. Codices hebraici biblioth., no. 351; and Richler and Beit-Arie, Hebrew Manuscripts in the Biblioteca Palatina, no. 1485.
} 
to the Bible, in which his name should appear. The following owner mentioned in the manuscript is Judah Navarro, who we know sold the Bible in Lisbon on 29 March 1384 to Moses de Leiria. ${ }^{44}$

This date evidently excludes the possibility of considering the owner's migration from Navarre to Portugal in relation with the 1391 riots, and leads us to look closer at the origin and settlement in Portugal of the Navarro family, who held the Ibn Gaon Bible from some moment in the fourteenth century until 1384. The first documented member of the Navarro family in Portugal is Moses de Santarém, personal physician to King Pedro I (reigned 1357-67) and appointed arraby mor ('Chief Rabbi') of Portugal with permission to adopt the name Navarro, a fact pointing to the original homeland of his family. ${ }^{45}$ Ferro Tavares states that Moses Navarro's family emigrated from Navarre and settled first in Santarém, then in Lisbon, during the reign of King Dinis I (12791325). ${ }^{46}$ As Moses Navarro is the first to adopt the name alluding to the family's original homeland, it may well be the case that his family migrated to Portugal during the first quarter of the fourteenth century. We know that BNF, MS Hébr. 21 was produced in 1301/02 by Ibn Gaon in Tudela, Navarre, for the physician Abraham de Leria, and that Judah Navarro sold this Bible in 1384 in Lisbon. These facts lead me to suggest that Abraham de Leria, or his son, emigrated from Tudela to Santarém and then to Lisbon at some point between 1302 and 1325, before the death of King Dinis I, and that the Bible remained in the family until 1384, when Judah Navarro sold it to Moses de Leiria. This suggestion is based on the assumption that Abraham de Leria would be an ancestor (grandfather?) of Moses de Santarém, and also of Judah Navarro, an assumption which is based on three facts: first, the Navarro family came from Navarre, and Abraham de Leria received the Ibn Gaon Bible in Tudela; second, Moses de Santarém was a physician, as was Abraham de Leria; and third, the Bible under discussion was in Tudela in 1302 and in Lisbon in 1384, owned by a person of the Navarro family, Judah Navarro, son of Moses Navarro. Moreover, the fact that Judah Navarro's father is mentioned in a deed in the manuscript as Moses Navarro might well indicate that he is the same Moses Navarro who was physician to King Pedro I. Yet all

\footnotetext{
${ }^{44}$ See below for discussion on the two deeds in this manuscript.

${ }^{45}$ Cf. Meyer Kayserling, História dos judeos em Portugal (Sao Paulo: Pioneira, 1971), p. 23.

${ }^{46}$ María José Pimenta Ferro Tavares, Los judíos en Portugal, Colecciones Mapfre 1492: Colección Sefarad (Madrid: Mapfre, 1992), p. 54.
} 
this should be considered with caution, as there is no absolute certainty on the many suggestions needed to link Abraham de Leria with Moses de Santarém, and both with Judah Navarro.

A few words should also be said about the person who bought the Bible from Judah Navarro in 1384 - Moses de Leiria. From a deed of claim, which I shall discuss further below, it is clear that the buyer and seller did not agree on the price to be paid for the book, a matter that led them to court at least twice over ten years. At the time when the deed was written (1396), Moses de Leiria was 'fisico de nosso senhor El-Rei, e arrabi mor das comunas dos judeos dos reinos de Portugal e do Algarve" ${ }^{47}$ ('Physician of our Lord the King, and Chief Rabbi of the Jewish communities in the Kingdoms of Portugal and the Algarve'). Moses de Leiria was appointed arrabi mor in 1391 and remained in office until 1405. Kayserling suggested that this Moses arrabi mor was a member of the Navarro family, ${ }^{48}$ just like the physician Moses Navarro and the treasurer Dom Judah; but Ferro Tavares claimed that Moses de Leiria was not related to the Navarro family. ${ }^{49}$ This claim is supported here by the fact that he is referred to as Moses de Leiria in the deed of claim in BNF, MS Hébr. 21, and not as Moses Navarro, in contrast to the other members of the Navarro family who are mentioned — Judah Navarro, son of Moses Navarro, and Solomon Navarro.

\section{Circulation and use}

In order to understand fully the circumstances of BNF, MS Hébr. 21 circulation and transmission, it is necessary to look more closely at the two deeds to be found in the manuscript. The first deed, on fol $371^{\mathrm{v}}$, is written in Portuguese with Hebrew script, and provides limited but key information for tracing the circumstances of the transmission of this Bible at the end of the fourteenth century. The deed is dated to 1422 of the Hispanic Era (1384 CE), as corroborated by the starting formula ' $\mathrm{Na}$ [era] de mil e quatrocentos e vinte e dous anos' ('in [Hispanic era] 1422'). It states that the Bible was sold on 29 March 1384 at a notary's office established in Samuel Masud's shop in Lisbon, for an unknown amount of 'libras de dineiros portugueses' ('Portuguese pounds'). The transaction is corroborated by the community's scribe, Joseph Pulgon,

\footnotetext{
${ }^{47}$ BNF, MS Hébr. 21, fol. 295r .

${ }^{48}$ Kayserling, História dos judeos em Portugal, p. 33.

${ }^{49}$ Pimenta Ferro Tavares, Los judíos en Portugal, p. 54.
} 
and three witnesses - Nissim bar Moses ben Crispin, Samuel bar Joseph Masud and Jacob Esquira. The names of seller and buyer have been erased in every place they had been written, as well as the amount paid for the Bible, a common practice in medieval Hebrew manuscripts, which could lead to legal complaints and disputes about the ownership and on the agreed price.

Before going any further, it should be remembered that 1384, the same year that BNF, MS Hébr. 21 was sold, was a year of turmoil in Portugal. After King Fernando I passed away in 1383, Queen Leonor took over the regency, while riots broke out in Lisbon against her and against the Jews, in particular against the Royal treasurer, Dom Judah, protégé of the Queen. The Queen was accused of being pro-Castilian — her daughter Beatriz was married to Juan I of Castile and they were therefore candidates for the throne of Portugal - and she escaped to Alenquer and Santarém while João, Grand Master of Aviz, assumed the regency on behalf of the Infante João, King Fernando's stepbrother. Dom Judah accompanied the Queen in her flight from Lisbon, and subsequently from Portugal to Castile. ${ }^{50}$ The civil war became a war with Castile, and Castilian troops arrived in Lisbon that same year of 1384. The war ended in 1385 with João I of Aviz acclaimed as king and the Castilians defeated in the battle of Aljubarrota.

A second deed in BNF, MS Hébr. 21 was written in a fourteenth-century Iberian courtesan script on fols $295^{\mathrm{v}}-96^{\mathrm{r}}$, two pages originally left blank between the end of Psalms and the beginning of Chronicles. It provides information concerning a claim. Previous studies of the manuscript have noted the presence of this deed, ${ }^{51}$ but it has been taken as a deed of sale and its transcription and study has been neglected to date, except for the names of two of the witnesses, who signed their names with Hebrew letters. ${ }^{52}$ Some excerpts from this document will allow us to understand in what way

\footnotetext{
${ }^{50}$ Cf. Kayserling, História dos judeos em Portugal, pp. 25-27.

${ }^{51}$ Sed-Rajna and Fellous, Les manuscrits hébreux enluminés, p. 46, where it is described as deed of sale.

52 Sed-Rajna and Fellous, Les manuscrits hébreux enluminés, mentions Nissim bar Moses ben Crispin and Samuel bar Joseph Masud, two of the witnesses in the previously mentioned deed of sale, the only two whose names are written in Hebrew. Other witnesses mentioned in this deed are: Liote, especieiro and Jose Branco, especieiro, but their signatures do not appear; Jento, especieiro, signed writing his name in Portuguese, and Solomon Navarro added his rubric to the document, for he acted as notary.
} 
this claim is linked with the previous deed of sale, and what problems are posed by the transaction: ${ }^{53}$

Saibam todos quantos este instrumento de venda virem que na era de mil e quatrocentos e trinta e quatro anos, doze dias de Outubro, em Lisboa, nas casas de morada de mestre Moises de Leiria, fisico de nosso senhor El-Rei, e arrabi mor das comunas dos judeus dos reinos de Portugal e do Algarve, em presença de mim Salomão Navarro, tabelião do dito senhor Rei [...], apareceu Judas Navarro, morador na dita cidade, filho de Moises Navarro, por si de uma parte, e dona Milia, mulher do dito mestre Moises, arrabi mor, em nome do dito seu marido da outra. E logo pelos sobreditos foi dito que entre eles era preito e demanda por razão deste livro de Biblia [...] que o dito Judas Navarro ora demandava ao dito arrabi mor, perante Vicente Domingues, juiz do civel na dita cidade de Lisboa, pedindo o dito Judas Navarro contra o dito arrabi mor que lhe desse o dito livro ou lhe pagasse por ele certa quantia [...]; foi dada sentença que o dito arrabi mor lhe pagasse certa quantia, segundo diziam que mais compridamente no dito feito era conteudo. Da qual sentença o dito arrabi apelara porque dizia a dita dona Milia pela parte do dito arrabi mor, seu marido, que o dito Judas Navarro lhe vendera o dito livro havia dois anos por noventa libras.

('Know all those who see this deed of sale that in the [Hispanic] era of 1434, on the twelfth of October, in Lisbon, in the home of Master Moses de Leiria, physician to our lord the King, and Chief Rabbi of the Jews of the Kingdoms of Portugal and the Algarve, in the presence of me, Solomon Navarro, notary of the said King [...] there appeared Judah Navarro, inhabitant of said city, the son of Moses Navarro, on the one hand, and on the other Dona Milia, wife of the said Master Moses, Chief Rabbi, on behalf of her husband. And then it was stated by the aforementioned that there was a claim between them because of this book of the Bible $[\ldots]$ that the said Judah Navarro was claiming from the Chief Rabbi, before Vicente Domingues, civil judge of the said city of Lisbon, [...] asking

\footnotetext{
${ }^{53}$ I would like to thank María José Pimenta Ferro Tavares, who kindly provided me with a complete transcription of the Portuguese deed. I would also like to thank María Jesús Torrens Álvarez and José Luis Ramírez Luengo, who helped me with the initial reading of the document.
} 
that the said Chief Rabbi should give him said book or pay a certain amount for it [...]; the verdict was that the said Chief Rabbi should pay a certain amount, which was set out in more detail in that deed. The Chief Rabbi appealed against this verdict, for Dona Milia said on behalf of the said Chief Rabbi, her husband, that the said Judah Navarro had sold him the book two years prior for ninety pounds'). ${ }^{54}$

This deed is thus dealing with the appeal by Moses de Leiria, arraby mor, ${ }^{55}$ which he had made ten years before. As the sale was dated in the other deed to 1384, the first claim took place in 1386. The following lines in the deed of claim elucidate the reason for the meeting:

E estando assim o dito feito para apelação ante os sobreditos perante Bartolomeu Martins e João Afonso Fuseiro, sobrejuizes do dito senhor Rei [...] desde logo que sobre isto filhou que o dito arrabi mor desse e pagasse ao dito Judas Navarro por todo o direito e acção que contra ele havia ou entendia de haver por razão do dito livro e custas e despesas que assim fizera mil e seiscentos libras desta moeda que ora corre real por dez soldos. E que o dito Judas Navarro desse por quite e por livre o dito arrabi mor [...] E logo o dito Judas Navarro disse que lhe praz de todo e conheceu e confessou que recebeu do dito arrabi mor as ditas mil e seiscentas libras por mão da dita dona Milia.

('And thus the matter being appealed against the aforesaid, before Bartolomeu Martins and João Afonso Fuseiro, sobrejuizes [senior judges] of the lord King [...] forthwith it was decreed that the Chief Rabbi should give and pay to Judah Navarro, for all the rights and actions there were or might be against him, for the said book and the costs and expenses, a total sum of one thousand six hundred pounds of the money that now gives one real for ten soldos. And that the said

\footnotetext{
${ }^{54}$ BNF, MS Hébr. 21, fol. 295'.

${ }^{55}$ It is worth mentioning that the post of arraby mor was vacant from 1383, when Judah Aben Menir, of Navarrese origin, left office after the King's death in 1383, until 1391 when King João I of Aviz appointed Moses de Leiria, previously unknown, as arraby mor. Cf. Pimenta Ferro Tavares, Los judios en Portugal, p. 54. This deed of claim in BNF, MS Hébr. 21 would attest that Moses de Leiria bought this Bible in Lisbon in 1384, many years before being appointed arraby mor.
} 
Judah Navarro should acquit and free the said Chief Rabbi [...] And then the said Judah Navarro declared that he was pleased with this and recognized and admitted that he had received from the said Chief Rabbi the said 1600 pounds from the hand of the said Dona Milia'). ${ }^{56}$

Once Moses de Leiria's appeal was rejected, he, represented by his wife, had to pay the decreed amount - 1600 pounds — to Judah Navarro. This deed thus witnesses the meeting in which such a sum was paid.

It is noteworthy that the deed of sale was written in Portuguese with Hebrew script, while the claim was written in Portuguese with Latin script. Moreover, the witnesses in the sale all signed their names in Hebrew, while one witness in the claim signed his name in Latin characters (Jento especieiro). The change of written code must be related to the fact that all the persons involved in the sale (seller, buyer, scribe, and witnesses) were Jews, and therefore the legal action was executed within the Jewish community, using its own code and written by the community's scribe, Joseph Pulgon. On the other hand, the claim involves civil judges (Bartolomeu Martins and João Afonso Fuseiro); in other words, it is documenting a legal action within the regular judicial system, not specifically within the Jewish community. For this reason it is written in Portuguese with Latin script by the King's notary, himself a Jew (Solomon Navarro), and in the presence of many other witnesses, among them the community's scribe, Nissim Crispin. ${ }^{57}$

Light is shed on the following stage in the journey of this Bible by a short note in Portuguese on fol 371 ${ }^{\mathrm{v}}$. It reads: 'Esta Bibilia a compei em sale no anno de 5388 dela atruxe-se de Abraham abensur' ('This Bible, I bought it in Salé in the year of 5388 from Abraham Abensur'). These words tell us a few things. First, there was a transaction in which the Bible was bought (a compei). Second, the transaction took place in Salé, Morocco; third, the buyer (or the family) was originally from Portugal, as he wrote in Portuguese, and is a Jew, for only a Jew would indicate the Jewish year $(5388=1628)$; and fourth, it belonged to Abraham Abensur, a member of a well-known family with

\footnotetext{
${ }^{56}$ BNF, MS Hébr. 21, fol. $295^{\mathrm{r}}$.

${ }^{57}$ Mentioned as 'escrivão' and acting as witness, the same role that he had taken in the deed of sale analysed above, where the community's scribe was Joseph Pulgon.
} 
origins in the Iberian Peninsula before $1492 .{ }^{58}$ In short, the Bible was taken to Salé, probably after the expulsion of the Jews from Portugal, and it remained there at least until 1628, when a Jew of Portuguese origin bought it from Abraham Abensur. ${ }^{59}$ Thus, the circulation of this Bible started in the early fourteenth century when it was taken to Portugal. There it was the property of the powerful Navarro family, who sold it to Moses de Leiria. No further information is available except for this note mentioning the purchase of the Bible in Salé, from where it arrived in Lyon, France, in the eighteenth century, whence it travelled to the Bibliothèque nationale de France.

Like this Bible, BNF, MS Hébr. 20 also made its way out of Navarre in the fourteenth century, in this case to Italy, as is known from the deed of sale in fol $466^{\mathrm{v}}$, dated to 1399. This deed states that the manuscript was bought in Bologna by Solomon ben Hasdai, and is worth mentioning for many reasons: it is the first sale recorded in the manuscript; it is located in Bologna at the turn of the fifteenth century; and it gives the exact date (1399) of the many interventions reflected in the manuscript, which trace ways of reading and ways of using the Bible. In what follows, we shall take a closer look both at BNF, MS Hébr. 20 journey to (and in) Italy, and at the use of the manuscript as reflected in its pages.

Deeds of sale and notes of transmission dated to the fourteenth century in Italy written in Sephardic manuscripts are more common than is generally supposed. BNF, MS Hébr. 7, ${ }^{60}$ a Bible copied in Perpignan (Roussillon, in present-day France) by Solomon bar Rafael in 1299 (just one year before the copy of BNF, MS Hébr. 20) also made its way to Italy in the fourteenth century, as can be discerned from an incomplete deed in fol $1^{\mathrm{v}}$ in which the date of the transaction, 1405, is still discernible, as is the

\footnotetext{
${ }^{58}$ Sed-Rajna and Fellous, Les manuscrits hébreux enluminés, p. 46, had already identified the name and the date, although the language in which this note was written is there described as Judeo-Spanish instead of Portuguese.

${ }^{59}$ The Bible probably entered the Bibliothèque nationale de France in 1794 from Lyon, as corroborated by an annotation written by Langlès, curator during the French Revolution; cf. Sed-Rajna and Fellous, Les manuscrits hébreux enluminés, p. 46.

${ }^{60}$ Described in Zotenberg and Steinschneider, Manuscrits orientaux, pp. 1-2; Sed-Rajna and Fellous, Les manuscrits hébreux enluminés, no. 12; Colette Sirat and Malachi Beit-Arié, Manuscrits médiévaux en caractères hébraïques portant des indications de date jusqu'à 1540 / Oșar kiteve-yad 'ivriyim mi-yeme ha-benayim be-siyyune ta'arikh 'ad shenat 5300, 3 vols (Paris: Centre National de la Recherche
} Scientifique; Jerusalem: Ha akademiah ha-le’umit ha-yisra'elit le-mada'im, 1972-86), I, no. 23; del Barco, Bibliothèque nationale de France, pp. 46-51. 
place where this was made, Camerino, a town in the province of Macerata, in the region of Le Marche. Further sales of the manuscript attest to the manuscript's Italian itinerary from Camerino to Recanati, in the same region of Le Marche, where the manuscript was bought in 1510, and a later journey to Istanbul, where it was subsequently acquired in the seventeenth century by the French ambassador, Achille de Harlay de Sancy. ${ }^{61}$

Another manuscript, BNF, MS Hébr. 30, ${ }^{62}$ copied in 1357 by Reuben bar Abraham ha-Ṣoref, most probably in Catalonia, was sold in 1432 and again in 1433 in the area of the Republic of Venice, as shown by the fact that it was paid for in Venetian currency. ${ }^{63}$ Again, the manuscript makes its way to Italy in the second half of the fourteenth century or, at the latest, in the first quarter of the fifteenth century, and, like BNF, MS Hébr. 7, it follows a subsequent itinerary within Italy. This includes the route from the Republic of Venice to Tivoli near Rome and to Ferrara, as attested by the many notes celebrating the birth of different owners' children (fol 414r). In fact, the Bible arrives in Ferrara in 1623, as reported in a statement recording the imprisonment in Florence of one of the owners from 1620 to 1622 (fol 414 ${ }^{\mathrm{v}}$ ), and ultimately left Italy for France only in the first quarter of the eighteenth century at the latest. ${ }^{64}$

Turning back to the Bible under discussion here, BNF, MS Hébr. 20, it arrived in Italy like the two other examples just mentioned at the very end of the fourteenth century, before 1399. The migration associated with the itinerary of these manuscripts must be connected with the 1391 riots which, as is well known, caused the decline and extinction of many Jewries across the Iberian Peninsula, as well as the flight to neighbouring Portugal and, across the Mediterranean, to Italy.

This route to Italy was most likely followed by this Bible after the 1391 riots, although earlier arrival in Italy cannot be discounted. Solomon ben Hasdai bought the manuscript in 1399 or more accurately at some point between September 1398 and June

\footnotetext{
${ }^{61}$ Deeds of sale in fols $1^{\mathrm{v}}$ and $517^{\mathrm{v}}$. On Harlay de Sancy's collection of Hebrew manuscripts, which he gave to the Oratoire de Paris when he joined this institution, see Richard, 'Achille de Harlay de Sancy et ses collections de manuscrits hébreux.'

${ }^{62}$ Described in Zotenberg and Steinschneider, Manuscrits orientaux, p. 4; Sed-Rajna and Fellous, Les manuscrits hébreux enluminés, no. 20; Sirat and Beit-Arié, Manuscrits médiévaux en caractères hébraïques, I, no. 44; del Barco, Bibliothèque nationale de France, pp. 198-203.

${ }^{63}$ BNF, MS Hébr. 30, fol. 414v: מכרנו זאת המקרא למ"ר אברהם בכ"ר צמח ז"ל צרפתי בשכר תשעים דוקטי' וויניציאני.

${ }^{64}$ The date of 1724 , terminus post quem non, is given by the use of the book-stamp no. 1 of the King's Library in fols $1^{\mathrm{r}}$ and $414^{\mathrm{v}}$. This book-stamp was not in use after that year.
} 
1399. ${ }^{65}$ During his ownership, he left numerous traces of his use of the Bible before selling it again, as stated in another deed of sale in the same manuscript (fol $468^{\mathrm{v}}$ ). There Solomon attested the sale of the Bible to Menahem ben Judah on the 15 of Tammuz 5159 (19 June 1399). As the year 5159 started on 12 September 1398, it seems clear that the manuscript was owned by Solomon ben Hasdai for a few months between September 1398, at the very earliest, and June 1399, when he sold the Bible in Cesena, less that ninety kilometres south-east of Bologna. However, he used the manuscript intensively before selling it to Menahem ben Judah. The traces of his use show us that, apart from being a scribe and perhaps a book dealer, he was a learned scholar with a deep knowledge of the Bible, the Midrash, and biblical exegesis.

Solomon ben Hasdai used BNF, MS Hébr. 20 as a reader and as a scribe. As a reader, he was mostly interested in the liturgical use of the Bible, and he therefore added calendar calculations, liturgical lists, and haftarot ('sections of the Prophets') indications. As a scribe, he revised the biblical text, writing some missing words and gaps in the margins, and adding over some prescribed letters the tagin ('crowns') ${ }^{66}$ intended for biblical scrolls. Furthermore, he copied some other texts in the margins or in blank spaces throughout the manuscript - the Alphabetic Midrash attributed to R. Akiva (fol 128v'), תיקון מזוזה ('Correction of the mezuzah'), including Deuteronomy 6. 4-9 and 11. 13-21 (fol 467 ), and the Scroll of Antiochus (fols $467^{\mathrm{v}}-68^{\mathrm{r}}$ ). ${ }^{67}$ This intensive activity carried out over a few months during the end of 1398 and the first half of 1399 contrasts with the passive ownership of the Bible by previous owners, and can only be understood on the basis that Ben Hasdai was not only an owner and reader of the manuscript, but an active user and scribe.

It seems that this Bible remained in Cesena for most of the century, as another deed of sale attests that Ben Porat Joseph ben Judah de Fano bought the Bible from Noah ben Solomon in the same city of Cesena in 1475 (fol $\left.468^{v}\right)$. Some years later, certainly before 1489 , Ben Porat Joseph sold the Bible to Judah de Norcia (fol $469^{\text {r }}$. ${ }^{68}$

\footnotetext{
${ }^{65}$ Only the year is given in the deed of sale: 5159 (September 1398 to August 1399). As the manuscript was sold again in Tammuz 5159 (June 1399), the first sale should have been before this date.

${ }^{66}$ The tagin consist of three vertical strokes above some prescribed consonants, thus receiving the name of 'crowns'.

${ }^{67}$ See the details of his additions in del Barco, Bibliothèque nationale de France, pp. 116-17.

${ }^{68}$ Judah de Fano recorded in the Bible the birth of his daughter Speranza in 1489. He therefore must have bought the Bible in that year at the very latest.
} 
The latter attests to a practice that is common among Italian Jews from the late fifteenth century onwards - the use of manuscripts as family records for the birth of children. These annotations are usually written in the blank pages at the beginning or at the end of the manuscripts. One of the most conspicuous cases in Bibles from the Bibliothèque nationale de France is the abovementioned BNF, MS Hébr. 30, in which no less than sixteen mentions of births, dated to the sixteenth and seventeenth centuries, are annotated by different owners (fol $414^{\mathrm{r}}$ ). In the case of the Bible under analysis here, Judah de Norcia recorded six births of which two are still discernible, those of his daughters Speranza and Benvenuta, dated 1489 and 1496, respectively (fol 469 ${ }^{\mathrm{r}}$ ).

There is no trace of any other sale or transmission of the Bible during the sixteenth or seventeenth century. However, traces of its use during the sixteenth and seventeenth centuries were left by some owners. This Bible records what must have been an infrequent event in the area of Ferrara - snow. This fact points out a practice — the recording of special occasions, particularly unusual meteorological events related to the abovementioned practice of recording births, a different type of special occasion. The place where it snowed is difficult to decipher, but the mention of the river Po might indicate the city of Ferrara or another town in the same area. This annotation gives the exact date of the event — Wednesday 17 December 5333 (1572). ${ }^{69}$ A different owner, Isaiah ben Judah de Macerata, copied his name in fol $3^{\mathrm{r}}$ together with some excerpts from the Zohar ('Book of Splendor'), in a cursive Italian script typical of the sixteenth and seventeenth centuries. In fol $10^{\mathrm{r}}$, he wrote a list of liquid measurements and two poems, the first of which contains an acrostic with his name Isaiah and an epithet - Alluf. The second poem is attributed to Jacob ben Meir Tam (Rabbenu Tam).${ }^{70}$ No city is mentioned apart from that in the name of the owner, Macerata. The Bible was later acquired by Louis d'Orléans in the first half of the eighteenth century and entered the Bibliothèque nationale de France in 1753. All the cities mentioned in the different deeds and in the names of the owners - Bologna, Cesena, Norcia, Fabriano, Fano, Macerata - are located in an area between Bologna in the north and Macerata, in central Italy close to the Adriatic sea. This is therefore the area in which

\footnotetext{
69 BNF, MS Hébr. 20, fol. 3r. היום יו' ד' שנת של"ג שהוא י"ז לחדש דיצימבר [...] שלג פה [...] נהר פה. It should be noted that the date is given using the Jewish year and the Christian month and day; the 17 December corresponded to 11 Tevet, and fell on Wednesday.

${ }^{70}$ BNF, MS Hébr. 20, fol. 10r: חרוז שעשה ר"ת על רביעית של תורה לישראל.
} 
Javier del Barco

BNF, MS Hébr. 20 circulated and was used between the late fourteenth and early eighteenth centuries before its journey to France. 


\section{Conclusion}

In this essay, I have aimed here to reconstruct key moments - those concerning production, circulation and use - in the history of two medieval books through the documents produced by those who wrote them, bought them, inherited them, and circulated them. These people related to the manuscripts in a very special way. 'The lives of books are those of their readers and owners, whose wounds and scars they bear', ${ }^{71}$ a statement which is so very true of Hebrew manuscripts for their history is determined by two crucial factors: migration and mobility. Their lives run parallel to those of their producers, owners, readers and users. Thus every medieval Hebrew book has formed part of the lives of different people and at the same time has had a life of its own, beginning at the very moment of its production and ending, for the moment, in a library or private collection.

Moreover, every medieval manuscript has had a three-faceted journey of its own: one involving people, one involving use, and one involving places. The three of them are interrelated, as we have been able to see by looking more closely at the history of the two Bibles of Ibn Gaon analysed here. Most Hebrew manuscripts have lived just such a journey, which in most cases are hidden in the pages of the books themselves. Revisiting the pages of Hebrew manuscripts in search of colophons, deeds of sale, notes of inheritance and any other kind of historical annotation is one of the two pillars of reconstructing the lives of medieval books; the other is a thorough codicological and paleographic analysis. Colophons, deeds and annotations are sometimes scarce, but sometimes surprise us with traces of the life of a particular person who owned or read a manuscript.

Works Cited

\section{Manuscripts}

Bermuda, Carl Alexander Trust for Art and Judaica, formerly London, Sassoon Library, MS 82

Dublin, Trinity College Library, MS 16

Florence, Biblioteca Medicea Laurenziana, MS III.1

\footnotetext{
${ }^{71}$ Biblias de Sefarad / Bibles of Sepharad, ed. by Esperanza Alfonso, Javier del Barco, M. Teresa Ortega Monasterio, and Arturo Prats (Madrid: Biblioteca Nacional de España, 2012), p. 346.
} 


\section{- MS II.1}

Lisbon, Biblioteca Nacional de Portugal, MS Il. 72 (Cervera Bible)

Moscow, National Library of Russia, MS Guenzburg 119

Oxford, Bodleian Library, MS Kennicott 2 (Second Kennicott Bible)

—, MS Opp. Add. $4^{\circ} 75$ and 76

Paris, Bibliothèque nationale de France, MS Hébr. 7

—, MS Hébr. 20

—, MS Hébr. 21

—, MS Hébr. 30

Parma, Biblioteca Palatina, MS Parm. 2275

—, MS Parm. 2938

—, MS Parm. 3290

\section{Secondary Works}

Alfonso, Esperanza, Javier del Barco, M. Teresa Ortega Monasterio, and Arturo Prats, eds, Biblias de Sefarad / Bibles of Sepharad, (Madrid: Biblioteca Nacional de España, 2012)

del Barco, Javier, Bibliothèque nationale de France: Hébreu 1 à 32; Manuscrits de la bible hébraïque, Manuscrits en caractères hébreux conservés dans les bibliothèques publiques de France (Turnhout: Brepols, 2011)

Baruchson-Arbib, Shifra, La culture livresque des juifs d'Italie à la fin de la Renaissance, Documents, études et répertoires (Paris: CNRS, 2001)

Bobichon, Philippe, and Georges Vajda, Bibliothèque nationale de France, Hébreu 669 à 703: Manuscrits de théologie, Manuscrits en caractères hébreux conservés dans les bibliothèques de France: Catalogues (Turnhout: Brepols, 2008)

Cantera Burgos, Francisco, 'Juderías medievales de la provincia de Soria', in Homenaje a Fray Justo Pérez de Urbel, O.S.B., 2 vols (Silos: Abadía, 1976), I, pp. 445-82

Catalogue of the Institute of Microfilmed Hebrew Manuscripts $\langle\underline{\text { http://aleph.nli.org.il/F/?func=file\&file_name=find-b\&local_base=nnlmss }>}$ [accessed 19 June 2012]

Di Donato, Silvia, Bibliothèque nationale de France, Hébreu 214 à 259: Commentaires bibliques, Manuscrits en caractères hébreux conservés dans les bibliothèques de France: Catalogues (Turnhout: Brepols, 2011) 
A Further Ninety-Seven Highly Important Hebrew Manuscripts from the Collection Formed by the Late David Solomon Sassoon [...]: Auction, Tuesday December 4, 1984 (New York: Sotheby’s 1984)

Garel, Michel, D’une main forte: Manuscrits hébreux des collections françaises (Paris: Seuil / Bibliothèque nationale, 1991)

Gutwirth, Eleazar, and Miguel Ángel Motis Dolader, 'Twenty-Six Jewish Libraries from Fifteenth-Century Spain', The Library: The Transactions of the Bibliographical Society, 18, no. 1 (1996), 27-53

Hacker, Joseph, and Adam Shear The Hebrew Book in Early Modern Italy, ed. by (Philadelphia: University of Pennsylvania Press, 2011)

Halevy-Goitein, Estelle, 'The Illuminated Manuscripts of Joshua ben Abraham ibn Gaon' (unpublished doctoral thesis, École Pratique des Hautes Études, 1982) Kayserling, Meyer, História dos judeos em Portugal (Sao Paulo: Pioneira, 1971) Kogman-Appel, Katrin, Jewish Book Art Between Islam and Christianity: The Decoration of Hebrew Bibles in Medieval Spain, The Medieval and Early Modern Iberian World (Leiden: Brill, 2004)

Metzger, Thérèse, 'Josué ben Abraham ibn Gaon et la masora du Ms. Iluminado 72 de la Biblioteca Nacional de Lisbonne', Codices manuscripti, 15, no. 5 (1990), 1-27 Narkiss, Bezalel, Hebrew Illuminated Manuscripts (Jerusalem: Encyclopaedia Judaica / MacMillan, 1969)

—, Aliza Cohen-Mushlin, and Anat Tcherikover, Hebrew Illuminated Manuscripts in the British Isles: A Catalogue Raisonné, 2 vols (Jerusalem: Oxford University Press for the Israel Academy of Sciences and Humanities and the British Academy, 1982), I: The Spanish and Portuguese Manuscripts

—, and Gabrielle Sed-Rajna, 'Manuscrits hébreux enluminés conservés dans les bibliothèques de France: Présentation et spécimen', Revue des études juives, 130, nos 2-4 (1971), 255-69

Neubauer, Adolf, and A. E. Cowley, Catalogue of the Hebrew Manuscripts in the Bodleian Library and in the College Libraries of Oxford, 2 vols (Oxford: Clarendon, 1886-1906)

Ortega-Monasterio, María Teresa, 'Las bibliotecas y sus manuscritos hebreos', in Catálogo de manuscritos hebreos de la Comunidad de Madrid, ed. by Javier del Barco, Serie A: Literatura Hispano-hebrea, 3 vols (Madrid: CSIC, 2003-06), II (2004), 19-43 
-, 'Las bibliotecas y sus manuscritos hebreos', in Catálogo de manuscritos hebreos de la Comunidad de Madrid, ed. by Javier del Barco, Serie A: Literatura Hispanohebrea, 3 vols (Madrid: CSIC, 2003-06), I (2003), 34-55

—, 'La Biblioteca de El Escorial: Sus fondos hebreos', in El manuscrito hebreo bíblico de la biblioteca de San Lorenzo de El Escorial, ed. by María Josefa Azcárraga Servet, Emilia Fernández Tejero, and María Teresa Ortega-Monasterio (Madrid: Testimonio, 2000), pp. 33-54

Pimenta Ferro Tavares, María José, Los judíos en Portugal, Colecciones Mapfre 1492: Colección Sefarad (Madrid: Mapfre, 1992)

Richard, Francis, 'Achille de Harlay de Sancy et ses collections de manuscrits hébreux', Revue des études juives, 149, no. 4 (1990), 417-47

Richler, Binyamin, and Malachi Beit-Arie, Hebrew Manuscripts in the Biblioteca Palatina in Parma: Catalogue (Jerusalem: Jewish National and University Library, 2001)

—, Malachi Beit-Arie, and Nurit Pasternak, Hebrew Manuscripts in the Vatican Library: Catalogue (Vatican City: Biblioteca Apostolica Vaticana, 2008) Riegler, Michael, 'Colophons of Medieval Hebrew Manuscripts as Historical Sources' [in Hebrew] (unpublished doctoral thesis, The Hebrew University of Jerusalem, 1995)

De Rossi, Giovanni Bernardo, Mss. Codices hebraici biblioth. I. B. De Rossi accurate ab eodem descripti et illustrati (Parma: Ex Publico Typographeo, 1803)

Roth, Cecil, 'A Masterpiece of Medieval Spanish-Jewish Art: The Kennicott Bible', in Gleanings; Essays in Jewish History, Letters, and Art (New York: Published by Hermon Press for Bloch, 1967), pp. 298-321

Sassoon, David Solomon, Ohel Dawid: Descriptive Catalogue of the Hebrew and Samaritan Manuscripts in the Sassoon Library, London, 2 vols (London: Oxford University Press, H. Milford, 1932)

Schmelzer, Menahem, 'A Fifteenth- Century Hebrew Book List', Studies in Bibliography and Booklore, 20 (1998), 89-98

—, 'Hebrew Manuscripts and Printed Books among the Sephardim Before and After the Expulsion', in Crisis and Creativity in the Sephardic World, 1391-1648, ed. by Benjamin R. Gampel (New York: Columbia University Press, 1997), pp. 257-66 
Sed-Rajna, Gabrielle, and Sonia Fellous, Les manuscrits hébreux enluminés des bibliothèques de France, ed. by Maurits Smeyers, Corpus van verluchte handschriften $=$ Corpus of Illuminated Manuscripts (Leuven: Peeters, 1994)

Sirat, Colette, Hebrew Manuscripts of the Middle Ages (Cambridge: Cambridge University Press, 2002)

—, 'Notes sur la circulation des livres entre Juifs et Chrétiens au Moyen Age', in $D u$ copiste au collectionneur: Mélanges d'histoire des textes et des bibliothèques en l'honneur d'André Vernet, ed. by Donatella Nebbiai-Dalla Guarda and JeanFrançois Genest (Turnhout: Brepols, 1999), 383-403

_, and Malachi Beit-Arié, Manuscrits médiévaux en caractères hébraïques portant des indications de date jusqu'à 1540 / Oșar kiteve-yad 'ivriyim mi-yeme ha-benayim be-șiyyune ta'arikh 'ad shenat 5300, 3 vols (Paris: Centre National de la Recherche Scientifique; Jerusalem: Ha akademiah ha-le’umit ha-yisra'elit le-mada ‘im, 197286)

Zotenberg, Hermann, and Moritz Steinschneider, Manuscrits orientaux: Catalogues des manuscrits hébreux et samaritains de la Bibliothèque impériale (Paris: Imprimerie Impériale, 1866) 